\title{
Waste poly(methylene methacrylate) as precursor for activated carbons (Rapid communication)
}

\author{
Grzegorz Makomaski ${ }^{1),}$, Janusz Zieliński ${ }^{1)}$ \\ DOI: dx.doi.org/10.14314/polimery.2018.11.11
}

\begin{abstract}
The evaluation of the possibilities to use of waste poly(methylene methacrylate) (PMMA) in a composition with coal-tar pitch (CTP) for the preparation of activated carbons was carried out. The polymer-pitch compositions (PMMA-CTP), containing from 10 to $50 \mathrm{wt} \%$ of waste PMMA were homogenized at $270{ }^{\circ} \mathrm{C}$, for 1 hour. PMMA-CTP compositions were carbonized and activated with steam, carbon dioxide or potassium hydroxide. It was found that the activated carbon obtained from the composition containing $50 \mathrm{wt} \%$ of waste PMMA in the activation process with $\mathrm{KOH}$ was characterized by the highest iodine number $(I N=2260 \mathrm{mg} / \mathrm{g})$, methylene blue number $\left(M B=33 \mathrm{~cm}^{3}\right)$, specific surface area $\left(B E T=3134 \mathrm{~m}^{2} / \mathrm{g}\right)$, micropores $\left(1.033 \mathrm{~cm}^{3} / \mathrm{g}\right)$ and mesopores $\left(0.160 \mathrm{~cm}^{3} / \mathrm{g}\right)$ volume.

Keywords: poly(methylene methacrylate), coal-tar pitch, polymer-pitch compositions, activated carbons.

\section{Odpadowy poli(metakrylanu metylu) jako prekursor do otrzymywania węgli aktywnych}

Streszczenie: Przedstawiono wyniki badań dotyczących wykorzystania odpadowego poli(metakrylanu metylu) (PMMA) w mieszaninie z pakiem węglowym (CTP) do otrzymywania węgli aktywnych. Kompozycje polimerowo-pakowe (PMMA-CTP), zawierające od $10 \%$ mas. do $50 \%$ mas. odpadu PMMA, sporządzano $\mathrm{w}$ temp. $270{ }^{\circ} \mathrm{C} \mathrm{w}$ ciągu 1 godz., a następnie poddano karbonizacji i aktywacji parą wodną, ditlenkiem węgla lub wodorotlenkiem potasu. Stwierdzono, że największą liczbą jodową $(I N=2260 \mathrm{mg} / \mathrm{g})$, liczbą metylenową $\left(M B=33 \mathrm{~cm}^{3}\right)$, powierzchnią właściwą $\left(B E T=3134 \mathrm{~m}^{2} / \mathrm{g}\right)$ oraz objętością mikroporów $\left(1,033 \mathrm{~cm}^{3} / \mathrm{g}\right)$ i mezoporów $\left(0,160 \mathrm{~cm}^{3} / \mathrm{g}\right)$ charakteryzował się węgiel aktywny otrzymany z kompozycji zawierającej 50 \% mas. odpadu PMMA w procesie aktywacji KOH.
\end{abstract}

Słowa kluczowe: poli(metakrylan metylu), pak węglowy, kompozycje polimerowo-pakowe, węgiel aktywny.

Activated carbons, because of good mechanical durability, well-developed specific surface area and good sorption properties, both out of gaseous and liquid phases, have been widely used in many branches of industry $[1,2]$.

Traditionally, activated carbons have been obtained from natural feedstocks, such as hard coal, lignite, wood, peat, fruit stones, nutshells and coffee industry waste materials [3-6]. Literature data have shown that some natural polymers, such as cellulose, as well as synthetic polymers [7] and their waste [8] can be used for the production of activated carbons. From poly(ethylene terephthalate), Moura et al. [9] have obtained nanoporous

\footnotetext{
1) Warsaw University of Technology, Faculty of Civil Engineering, Mechanics and Petrochemistry, Lukasiewicza 17, 09-400 Plock, Poland.

*) Author for correspondence:

e-mail: Grzegorz.Makomaski@pw.edu.pl
}

carbon adsorbents of specific surface area up to $2176 \mathrm{~m}^{2} / \mathrm{g}$ and total volume of pores up to $1.035 \mathrm{~cm}^{3} / \mathrm{g}$, useful for the separation of $\mathrm{CO}_{2}$ from flue gas. Similarly, from waste poly(ethylene terephthalate), through activation with $3 \mathrm{MgCO}_{3} \cdot \mathrm{Mg}(\mathrm{OH})_{2} \cdot 3 \mathrm{H}_{2} \mathrm{O}$, Przepiórski et al. [10] have obtained mesoporous activated carbons of specific surface area up to $1984 \mathrm{~m}^{2} / \mathrm{g}$. In yet other papers [11,12] it has been reported that novolak resin mixed with hexamethylenetetramine and poly(vinyl butyral) or poly(oxyethylene)diol can be applied in preparation of activated carbons having specific surface area up to $1610 \mathrm{~m}^{2} / \mathrm{g}$.

At the Institute of Chemistry, Warsaw University of Technology in Plock, we have been carrying out studies on bitumen-polymeric materials for several years now. They are aimed at the improvement of utility properties of coal-originated bitumen and utilization of waste polymers [13]. Makomaski et al. [14-16] have proved that polymer-pitch compositions can be used for the preparation of activated carbons. 
This paper presents the results of studies on how waste poly(methylene methacrylate) can be successfully applied in the production of activated carbons.

\section{EXPERIMENTAL PART}

\section{Materials}

In this study were used the following raw materials:

- waste poly(methylene methacrylate) (PMMA), coming from the automotive industry,

- coal-tar pitch (CTP), with softening point $S P=107^{\circ} \mathrm{C}$, coking value $C V=53.03 \mathrm{wt} \%$, content of components insoluble in quinoline $Q I=7.14 \mathrm{wt} \%$, from Institute for Chemical Processing of Coal in Zabrze.

\section{Preparation of polymer-pitch compositions and derived activated carbons}

Polymer-pitch compositions containing from 10 to $50 \mathrm{wt} \%$ waste were prepared in the conditions allowing to obtain homogeneous and stable mixtures. The highest concentration of waste PMMA allowing to obtain a homogeneous phase with coal-tar pitch was $50 \mathrm{wt} \%$. The components of composition were homogenized in the temperature of $270{ }^{\circ} \mathrm{C}$, for 1 hour.

Formed polymer-pitch compositions and coal-tar pitch were carbonized and activated by steam $\left(\mathrm{H}_{2} \mathrm{O}\right)$, carbon dioxide $\left(\mathrm{CO}_{2}\right)$ or potassium hydroxide $(\mathrm{KOH})$.

Carbonization was carried out in two stages:

- phase one, of initial carbonization, performed in a vertical electric furnace by heating the sample to the temperature of $520{ }^{\circ} \mathrm{C}$ at the heating rate of $5{ }^{\circ} \mathrm{C} / \mathrm{min}$, in nitrogen atmosphere, and annealing it in this temperature for 1 hour,

- phase two, executed in a horizontal furnace type PRC-50/1200M (produced by CZYLOK) by heating the sample to the temperature of $520^{\circ} \mathrm{C}$ at the heating rate of $15{ }^{\circ} \mathrm{C} / \mathrm{min}$, and then to $850{ }^{\circ} \mathrm{C}$ at the heating rate of $10^{\circ} \mathrm{C} / \mathrm{min}$. The sample was annealed at $850^{\circ} \mathrm{C}$ for 1 hour.

Resulting carbonizates were activated in a vertical furnace type PRCm-33/1000 (produced by CZYLOK) with steam at $800{ }^{\circ} \mathrm{C}$ or with carbon dioxide at $850{ }^{\circ} \mathrm{C}$, to $50 \%$ burn-off.

Additionally, for both polymer-pitch compositions and coal-tar pitch, the process of carbonization and chemical activation with $\mathrm{KOH}$ was carried out. In order to achieve this, samples were initially carbonized at $520^{\circ} \mathrm{C}$ and sub- sequently chemically activated. The mixture of pulverized $\mathrm{KOH}$ and the product of initial carbonization (mass ratio of $3: 1$ ) was heated in a horizontal furnace type $\mathrm{PRC}-50 / 1200 \mathrm{M}$ to the temperature of $800{ }^{\circ} \mathrm{C}$ at the heating rate of $10{ }^{\circ} \mathrm{C} / \mathrm{min}$, and then annealed in this temperature for 1 hour. The process was carried out in nitrogen atmosphere (nitrogen flow rate of $20 \mathrm{dm}^{3} / \mathrm{h}$ ). After the completion of this process, the product was cooled, rinsed with distilled water, $5 \%$ solution of hydrochloric acid and then with hot distilled water until a neutral reaction was reached.

\section{Methods of testing}

For coal-tar pitch and polymer-pitch compositions, the following measurements were carried out: softening point by "Ring and Ball" method (SP) according to the PN-EN 1427:2015-08 standard; coking value $(C V)$ according to the PN-C-97093:1993 standard; content of components insoluble in toluene (TI) according to the method elaborated at the Institute of Chemistry, Warsaw University of Technology in Plock [17]; content of components insoluble in quinoline $(Q I)$ according to the PN-C-97058:1999 standard.

For activated carbons, obtained in this way, the following parameters were determined: iodine number (IN) according to PN-C-97555.04:1983 standard and methylene blue number $(M B)$ according to PN-C-97555.03:1982 standard. Pore parameters in the obtained activated carbons were evaluated from the nitrogen adsorption/desorption isotherms at $77 \mathrm{~K}\left(\sim 350{ }^{\circ} \mathrm{C}\right)$, using Quantachrome Autosorb 1C analyzer. Specific surface area was determined by the Brunauer-Emmett-Teller (BET) method. The micropore volume, micropore surface area and average pore width were determined by Dubinin-Radushkevich method. The mesopore volume and mesopore surface area were determined by Barrett-Joyner-Halenda method.

\section{RESULTS AND DISCUSSION}

Selected results of measurements of physicochemical properties of coal-tar pitch (CTP) and polymer-pitch compositions (PMMA-CTP) are presented in Table 1.

Waste PMMA affected the change of physicochemical properties of coal-tar pitch. The scope and direction of changes depended on the amount of polymeric modifier.

\section{T a b 1 e 1. Physicochemical properties of the coal-tar pitch and PMMA-CTP compositions}

\begin{tabular}{c|c|c|c|c}
\hline $\begin{array}{c}\text { Compositions } \\
\text { wt } \%\end{array}$ & $\begin{array}{c}S P \\
{ }^{\circ} \mathrm{C}\end{array}$ & $\begin{array}{c}C V \\
\text { wt } \%\end{array}$ & $\begin{array}{c}T I \\
\text { wt } \%\end{array}$ & $\begin{array}{c}\text { QI } \\
\text { wt \% }\end{array}$ \\
\hline CTP & 107.0 & 53.0 & 34.2 & 7.1 \\
10 PMMA + 90 CTP & 137.0 & 60.1 & 35.0 & 8.8 \\
25 PMMA + 75 CTP & 145.0 & 48.3 & 29.4 & 9.2 \\
50 PMMA + 50 CTP & 200.0 & 28.8 & 23.0 & 10.5 \\
\hline
\end{tabular}

$S P$ - softening point, $C V$ - coking value, $T I$ - content of components insoluble in toluene, $Q I$ - content of components insoluble in quinoline. 
T a b $\quad 1$ e 2 . Sorption properties of activated carbons from coal-tar pitch and PMMA-CTP compositions

\begin{tabular}{c|c|c}
\hline $\begin{array}{c}\text { Compositions } \\
\text { wt } \%\end{array}$ & $\begin{array}{c}\text { IN } \\
\text { mg/g }\end{array}$ & $\begin{array}{c}\text { MB } \\
\mathrm{cm}^{3}\end{array}$ \\
\hline \multicolumn{3}{c}{ Activated with steam } \\
\hline CTP & 580 & 4 \\
25 PMMA + 75 CTP & 560 & 4 \\
50 PMMA + 50 CTP & 640 & 5 \\
\hline \multicolumn{2}{c}{ Activated with carbon dioxide } \\
\hline CTP & 600 & 5 \\
10 PMMA + 90 CTP & 530 & 10 \\
25 PMMA + 75 CTP & 690 & 13 \\
50 PMMA + 50 CTP & 710 & 15 \\
\hline \multicolumn{2}{c}{ Activated with potassium hydroxide } \\
\hline CTP & 1010 & 9 \\
10 PMMA + 90 CTP & 2220 & 26 \\
50 PMMA + 50 CTP & 2230 & 28 \\
\hline
\end{tabular}

$I N$ - iodine number, $M B$ - methylene blue number.

The softening point kept increasing with the increase of waste PMMA in the compositions. The highest softening point was revealed by the composition containing $50 \mathrm{wt} \%$ of waste PMMA.

Addition of waste PMMA into CTP caused the decrease of both coking value and residue yield after the process of high-temperature carbonization. An exception to this rule was the composition containing $10 \mathrm{wt} \%$ of waste PMMA, which had higher coking value than CTP (by $7.1 \mathrm{wt} \%$ ). In particular, significant changes occurred for compositions containing $50 \mathrm{wt} \%$ of the waste, where coking value was lower by $24.2 \mathrm{wt} \%$ compared to coal-tar pitch. Addition of waste PMMA in the amount of 10 or $50 \mathrm{wt} \%$ into coal-tar pitch caused changes of group composition of the bitumen. It was observed that the increase of waste PMMA addition into CTP caused the decrease of content of TI components and the increase of content of QI components. The PMMA-CTP compositions had a lower content of TI components and a higher content of QI components compared to coal-tar pitch. An exception to this rule was the composition containing $10 \mathrm{wt} \%$ of waste PMMA, which had higher content of TI components by $0.8 \mathrm{wt} \%$ compared to CTP.

The results of sorption properties measurements of activated carbons obtained from coal-tar pitch and PMMA-CTP compositions in the process of activation with steam, carbon dioxide, or potassium hydroxide are presented in Table 2.

These results provide evidence that sorption properties of activated carbons prepared from PMMA-CTP compositions were affected by the amount of polymeric waste added to the coal-tar pitch as well as by the type of the activating agent. It was found that, in the majority of cases,
$\mathrm{T}$ a $\mathrm{b} 1$ e 3 . Results of porous structure of activated carbons obtained from 50 wt \% PMMA + 50 wt \% CTP composition

\begin{tabular}{l|c|c|c}
\hline \multirow{2}{*}{ Parameter } & \multicolumn{3}{c}{ Activating agent } \\
\cline { 2 - 4 } & $\mathrm{H}_{2} \mathrm{O}$ & $\mathrm{CO}_{2}$ & $\mathrm{KOH}$ \\
\hline BET surface area, $\mathrm{m}^{2} / \mathrm{g}$ & 401 & 326 & 3134 \\
\hline \multicolumn{4}{c}{ Micropores (Dubinin-Radushkevich) } \\
\hline Micropore volume, $\mathrm{cm}^{3} / \mathrm{g}$ & 0.152 & 0.123 & 1.033 \\
Micropore surface area, $\mathrm{m}^{2} / \mathrm{g}$ & 427 & 345 & 2905 \\
Average pore width, $\mathrm{nm}$ & 1.37 & 1.49 & 1.67 \\
\hline \multicolumn{4}{c}{ Mesopores (Barrett-Joyner-Halenda) } \\
\hline Mesopore volume, $\mathrm{cm}^{3} / \mathrm{g}$ & 0.036 & 0.051 & 0.160 \\
Mesopore surface area, $\mathrm{m}^{2} / \mathrm{g}$ & 27 & 36 & 96 \\
\hline
\end{tabular}

addition of waste PMMA into coal-tar pitch caused the increase of iodine and methylene blue of obtained activated carbons. The exception to that rule was observed for compositions containing $<25 \mathrm{wt} \%$ of PMMA (activation with steam or carbon dioxide), which exhibited lower values of iodine number and similar values of methylene blue number, compared to activated carbon obtained from coal-tar pitch.

Addition of $10 \mathrm{wt} \%$ of waste PMMA into coal-tar pitch caused significant increase of iodine number and methylene blue number of carbon adsorbents prepared in the process of activation with potassium hydroxide. Further increase of the amount of this plastic waste resulted in relatively insignificant changes of these values.

While assessing the efficiency of applied activating agents on sorption properties of carbon adsorbents obtained from PMMA-CTP compositions, it was found that activated carbons obtained in the process of activation with $\mathrm{KOH}$ had significantly higher values of iodine number and methylene blue number than carbon adsorbents prepared in the process of activation with steam or carbon dioxide.

Additionally, nitrogen adsorption and desorption measurements were carried out for activated carbons obtained from the compositions containing $50 \mathrm{wt} \%$ of waste PMMA in the process of activation by means of steam, carbon dioxide, or potassium hydroxide. Table 3 contains the parameters of their porous structure.

Comparison of porous structure parameters for activated carbons obtained from compositions containing $50 \mathrm{wt} \%$ of PMMA points out to a meaningful role of the type of activating agent on their porous structure. The carbon adsorbents obtained in the process of activation with potassium hydroxide displayed the largest $B E T$ surface area, volume and specific surface area of micropores and mesopores, and the average pore width of micropores. Furthermore, the porous materials which were obtained in the process of activation with carbon dioxide displayed the lowest $B E T$ surface area as well as volume and specific surface area of micropores. On the other hand, adsorbents which were obtained in the process of activation with steam displayed the lowest total 
pore volume as well as volume and specific surface area of mesopores.

\section{CONCLUSIONS}

The results account for the possibility of obtaining activated carbons from polymer-pitch compositions containing waste poly(methylene methacrylate). The use of untypical feedstock, as an effect of combination of bituminous substance with polymeric waste and improvement of the methods of production, creates potential possibility to produce carbon adsorbents of interesting properties and porous structure.

Changes of physicochemical properties of coal-tar pitch are apparently dependent on the amount of added polymeric waste. By increasing the amount of waste PMMA into coal-tar pitch, the softening point (up to $200^{\circ} \mathrm{C}$ ) as well as the amount of components insoluble in quinoline (up to $10.5 \mathrm{wt} \%$ ) kept increasing, while coking value (down to $28.8 \mathrm{wt} \%$ ) and the amount of components insoluble in toluene (down to $23 \mathrm{wt} \%$ ) in PMMA-CTP compositions dropped.

It is claimed that while increasing the amount of waste PMMA in the compositions, both the iodine number and methylene blue number, to a much lesser degree, keep decreasing of obtained activated carbons. Activated carbon of the largest BET surface area and well-developed microporous structure was made from the composition containing $50 \mathrm{wt} \%$ of waste PMMA, activated with potassium hydroxide.

\section{REFERENCES}

[1] Bansal R.C., Goyal M.: "Activated Carbon Adsorption", CRC Press, New York 2005, pp. 1-8.

[2] Thommes M., Kaneko K., Neimark A.V. et al.: Pure and Applied Chemistry 2015, 87, 1052. https://doi.org/10.1515/pac-2014-1117

[3] Rashidi N.A., Yusup S.: Journal of Cleaner Production 2017, 168, 474. https://doi.org/10.1016/j.jclepro.2017.09.045

[4] Balsamo M., Tsyntsarski B., Erto A. et al.: Adsorption 2015, 21, 633. https://doi.org/10.1007/s10450-015-9711-7

[5] Nowicki P., Skibiszewska P., Pietrzak R.: Adsorption 2013, 19, 521.

https://doi.org/10.1007/s10450-013-9474-y

[6] Kundu A., Gupta B.S., Hashim M.A. et al.: Journal of Cleaner Production 2015, 105, 420.

https://doi.org/10.1016/j.jclepro.2014.06.093

[7] Choma J., Stachurska K., Marszewski M. et al.: Adsorption 2016, 22, 581. https://doi.org/10.1007/s10450-015-9734-0

[8] Bratek W., Świątkowski A., Pakuła M. et al.: Journal of Analytical and Applied Pyrolysis 2013, 100, 192. http://dx.doi.org/10.1016/j.jaap.2012.12.021

[9] Moura P.A., Vilarrasa-Garcia E., Maia D.A. et al.: Adsorption 2018, 24, 279. https://doi.org/10.1007/s10450-018-9943-4

[10] Przepiórski J., Karolczyk J., Takeda K. et al.: Industrial \& Engineering Chemistry Research 2009, 48, 7110. https://pubs.acs.org/doi/pdf/10.1021/ie801694t

[11] Yang J., Ling L., Liu L. et al.: Carbon 2002, 40, 911. https://doi.org/10.1016/S0008-6223(01)00222-6

[12] Cai Q., Huang Z., Kang F. et al.: Carbon 2004, 42, 775. https://doi.org/10.1016/j.carbon.2004.01.042

[13] Ciesińska W.: Polimery 2015, 60, 144. http://dx.doi.org/10.14314/polimery.2015.144

[14] Makomaski G., Zieliński J., Zdziarski M.: Przemyst Chemiczny 2015, 94, 694. http://dx.doi.org/10.15199/62.2015.5.6

[15] Makomaski G., Ciesińska W., Zieliński J.: Polimery 2012, 57, 635. http://dx.doi.org/10.14314/polimery.2012.635

[16] Makomaski G.: Przemyst Chemiczny 2016, 95, 1378. http://dx.doi.org/10.15199/62.2016.7.19

[17] Zieliński J., Osowiecka B., Liszyńska B. et al.: Fuel 1996, 75, 1543. https://doi.org/10.1016/0016-2361(96)00115-9

Received 6 V 2018 